\title{
EVALUATION OF NEUROPATHIC PAIN SCALE KNOWLEDGE
}

\author{
AVALIAÇÃO DO CONHECIMENTO DE ESCALA DE DOR NEUROPÁTICA \\ EVALUACIÓN DEL CONOCIMIENTO DE ESCALA DE DOLOR NEUROPÁTICO
}

\author{
Marcos Antônio Ribeiro de Menezes Lopes, ${ }^{1,2,3}$ Maurício Alcântara Angelim, ${ }^{4,5}$ Davi Dominguez Sousa ${ }^{6}$ \\ 1. Sociedade Brasileira de Ortopedia e Traumatologia, São Paulo, SP, Brazil. \\ 2. Sociedade Brasileira de Coluna, São Paulo, SP, Brazil. \\ 3. Clínica Ortoped, Salvador, BA, Brazil. \\ 4. Hospital Geral Sermege. Camaçari, BA, Brazil. \\ 5. Clínica de Tratamento da Dor- CTD. Salvador, BA, Brazil. \\ 6. Polícia Militar do Estado da Bahia. Bahia, BA, Brazil.
}

\begin{abstract}
Objectives: Neuropathic pain (ND) is defined as "one that results from injury or disease that directly affects the somatosensory system", differing from other types of pain in terms of symptoms, mechanisms and therapeutics, being the early diagnosis prerequisite for the appropriate management. Pain evaluation scales are very useful in clinical diagnosis. It is critical that orthopedic doctors are familiar with such tools. The objective was to evaluate whether the orthopedic physicians in Salvador know the tools of evaluation and clinical diagnosis of neuropathic pain (ND), as well as to determine which method of evaluation of ND is most used in their clinical practice. Methods: Data were analyzed from 74 orthopedic physicians working in the city of Salvador, who were interviewed from January to November 2017. Data were collected through a structured questionnaire consisting of subjective and objective questions and analyzed with SPSS 22.0 software. Results: Among the interviewed physicians, $41.9 \%$ knew some of the scales and, of these, $64.5 \%$ used in their clinical practice, being $70.3 \%$ of the total sample. The LANSS scale was used by $25.8 \%$ of the physicians in their practice as a tool to diagnose neuropathic pain, $22.6 \%$ used DN4 and $35.5 \%$ did not use any. Conclusions: The orthopedic physicians know little about the tools of evaluation and diagnosis of neuropathic pain and those with greater time of activity know less these tools than those who have less time. Many who know the tools do not use them in their clinical practice. LANSS and DN4 are the most commonly used scales. Level of Evidence III; Cross Sectional Study.
\end{abstract}

Keywords: Diagnosis; Neuralgia; Orthopedists; Scales.

\section{RESUMO}

Objetivo: A dor neuropática (DN) é definida como "aquela decorrente de lesão ou doença que afeta diretamente o sistema somatossensitivo", diferindo de outros tipos de dor em termos de sintomas, mecanismos e terapêutica, sendo o diagnóstico precoce pré-requisito para um manejo apropriado. As escalas de avaliação de dor são de grande utilidade para o diagnóstico clínico. É fundamental que os médicos ortopedistas estejam familiarizados com tais ferramentas. Avaliar se os médicos ortopedistas de Salvador conhecem as ferramentas de avaliação e diagnóstico clínico de dor neuropática (DN), bem como determinar qual o método de avaliação de DN mais utilizado em seus atendimentos. Métodos: Foram analisados os dados de 74 médicos ortopedistas atuantes na cidade de Salvador, entrevistados no período de janeiro a novembro de 2017. Os dados foram coletados através de questionário estruturado constituído por perguntas subjetivas e objetivas e analisados com o software SPSS 22.0. Resultados: Dentre os médicos entrevistados, 41,9\% conhecem alguma das escalas e, destes, $64,5 \%$ utilizam em sua prática clínica, sendo 70,3\% da amostra total. A LANSS foi utilizada por 25,8\% dos médicos em sua prática como ferramenta para diagnosticar dor neuropática, 22,6\% utilizam a DN4 e 35,5\% não utilizam nenhuma. Conclusão: Os médicos ortopedistas conhecem pouco as ferramentas de avaliação e diagnóstico de dor neuropática e aqueles com maior tempo de atuação conhecem menos essas ferramentas do que os têm menor tempo. Muitos dos que conhecem as ferramentas não as usam em sua prática clínica. A LANSS e a DN4 são as escalas mais utilizadas. Nível de Evidência III; Estudo de Corte Transversal.

Descritores: Diagnóstico; Neuralgia; Ortopedistas; Escalas.

\section{RESUMEN}

Objetivo: El dolor neuropático (DN) se define como "resultado de una lesión o enfermedad que afecta directamente al sistema somatosensible", difiriendo de otros tipos de dolor en términos de síntomas, mecanismos y terapéutica. El diagnóstico precoz es pre-requisito para un manejo apropiado. Las escalas de evaluación de dolor son de gran utilidad para el diagnóstico clínico. Es fundamental que los médicos ortopedistas estén familiarizados con tales herramientas. El objetivo de este estudio fue evaluar si los médicos ortopedistas de Salvador conocen las herramientas de evaluación y diagnóstico clínico de dolor neuropático (DN), así como determinar cuál es el método de evaluación de DN más utilizado en sus atenciones. Métodos: Se analizaron los datos de 74 médicos ortopedistas actuantes en la ciudad de Salvador, entrevistados en el período de enero a noviembre de 2017. Los datos fueron recolectados a través de un cuestionario estructurado con preguntas subjetivas y objetivas y fueron analizados con el software SPSS 22.0. Resultados: Entre los médicos entrevistados, 41,9\% conocen alguna de las escalas y, de éstos, 64,5\% utilizan en su práctica clínica, siendo el 70,3\% de la muestra total. La LANSS fue utilizada por 25,8\% de los médicos en su práctica como herramienta para diagnosticar dolor neuropático, 22,6\% utilizan la DN4 y 35,5\% no utilizan ninguna. Conclusiones: Los médicos ortopedistas conocen poco las herramientas de evaluación y diagnóstico de dolor neuropático y aquellos con mayor tiempo de actuación conocen menos esas herramientas que los que tienen menos tiempo. Muchos de los que conocen las herramientas no las usan en su práctica clínica. La LANSS y la DN4 son las escalas más utilizadas. Nivel de Evidencia III; Estudio de Cohorte Transversal.

Descriptores: Diagnóstico; Neuralgia; Ortopedistas; Escalas. 


\section{INTRODUCTION}

Pain, despite being the most common reason for seeking healthcare services in Brazil, ${ }^{1}$ is still undertreated and is a cause of suffering and financial burden to individuals and to society. Neuropathic pain (NP) is defined as "that resulting from injury or illness that directly affects the somatosensory system". ${ }^{2}$ This relatively recent concept that NP also includes other characteristics, such as sensory pain symptoms that last beyond the healing period, among others. ${ }^{3}$ This is a chronic condition of varied prevalence considered difficult to control, associated with frequent treatment failure and high healthcare system costs, ${ }^{4}$ and causing suffering and disability for a great number of people. It is important to emphasize the impact of this condition on patient quality of life in relation to sleep disorders, depression, anxiety, work issues, the need for rehabilitation, in addition to psychiatric comorbidities. ${ }^{5}$

NP differs from other types of pain in terms of symptoms, mechanisms, and therapeutic management and is manifested in different ways, the most common being continuous burning pain, a sensation of shock, and allodynia, and early diagnosis is a prerequisite for proper management. For this reason, the basic concepts of a clinical examination for the patient suspected of neuropathic pain should be known to all clinicians who treat patients with pain. ${ }^{6}$ NP can be classified as spontaneous (burning, tightening, pressure) and provoked (stabbing and shock) by brushing against the skin, pressure, and/or by thermal stimulation. Patients with NP also complain of paresthesic symptoms, such as tingling, stabbing pains, and pin pricks, and the presence of hyperalgesia (increased response to a painful stimulus) is common. ${ }^{6}$

NP has received special attention due to the therapeutic refractoriness that it presents and to the development of diagnostic tools for recognizing this type of pain. ${ }^{7}$ In spite of the development of neurophysiological and neuroimaging methods, collecting patient history and conducting the patient physical examination using simple propaedeutic tools remains the most important step in the diagnostic process. It is necessary to have a basic knowledge of neuroanatomy and of the physical neurological examination and to use an analytical approach to the patient. ${ }^{8}$

Because NP manifests itself by means of various, complex symptoms with different pain patterns, patients who present it are notoriously difficult to identify. ${ }^{9}$ Identifying NP is one of the challenges in the daily clinical routine of physician specialists due to factors like the absence of signs of pathognomonic symptoms and a lack of definition around the correlation between physiopathological symptoms, signs, and mechanisms, among others. Nevertheless, clinical experience and the accurate evaluation of the patient by the physician will be able to overcome these difficulties and guide appropriate treatment. The semiological evaluation of the patient is the first elucidative step and, as such, the verbal descriptors of neuropathic pain and the assessment of its intensity using scales are valuable diagnostic elements.

Pain assessment scales, such as DN4, Pain-DETECT, and IDpain, among others, are very useful tools for clinical diagnosis that aim to differentiate neuropathic pain from non-neuropathic pain. ${ }^{9}$ The development of these tools for screening and evaluating of NP facilitate its diagnosis and differentiation from other types of pain without a neuropathic component.

These tools offer high sensitivity and specificity, being of great use in the clinical practice of physicians who treat patients with chronic pain. Stump et al., for example, argue that for patients with lumbosciatalgia the precise diagnosis of the pain pattern is essential for obtaining the best therapeutic results and it is essential to use an NP assessment tool to evaluate the type of pain. ${ }^{10}$

The healthcare of patients who suffer from chronic pain must always include an evaluation of the pain and its impact on the individuals' lives, and thus, the development of educational programs for pain treatment specialists is of notable importance. It is known that NP can be relieved in a large number of patients with simple treatment algorithms. ${ }^{11}$ However, for physician specialists to be able to treat neuropathic pain, they have to have the knowledge necessary to easily identify it. As such, it is essential that they be familiar with the diagnostic tools and make them part of their clinical routine, since patients with neuropathic pain, many times will first seek care in orthopedic clinics, showing up without an established diagnosis and consequently without a suitable treatment plan for their condition.

\section{METHODS}

\section{Study design}

This was an observational, cross-sectional study conducted in the city of Salvador (BA), Brazil, in 2017 and approved by the Institutional Review Board of the Fundação Baiana de Cardiologia. Seventy-four orthopedic physicians from private clinics in Salvador were invited to participate.

\section{Sample size}

The sample was made up of 74 orthopedists who practice in private clinics in Salvador, provided they met the inclusion criteria and did not satisfy any of the exclusion criteria. All those who met the single criterion of being an orthopedist were admitted to the study.

\section{Data collection}

Data collection included basic identification data (work institution, time practicing, and education level) and specific questions relative to knowledge and utilization of the diagnostic tools. After reading and signing the informed consent form (ICF), those who agreed to participate answered a structured questionnaire consisting of subjective questions about personal data and two objective questions, namely 1) "Do you know about any of the neuropathic pain evaluation scales listed below?", the options for which were a) LANSS, b) DN4, c) NPS, d) NPSI, e) PainDetect, f) none of the above; and 2) "Which clinical-diagnostic evaluation of the neuropathic component do you use in your clinical practice?". The data were collected between January and November of 2017. No data was collected from secondary sources.

\section{Statistical analysis}

The data were entered into an Excel(C) database. Statistical analysis was processed using the Statistical Package for the Social Sciences (SPSS) version 22.0 software. Absolute frequencies and percentages were used for the nominal variables. The variables analyzed were knowledge of neuropathic pain diagnostic tools, use of the tools, and length of experience. For length of experience, the median, and interquartile interval were described, the mean being used for comparison with the variable "knowledge of the scales". The Spearman test was used to correlate the non-parametric variables. The level of significance adopted was $5 \%$.

\section{RESULTS}

The population studied was made up of 74 orthopedic physicians practicing in the city of Salvador, 64 of whom $(86.5 \%$ of those who responded to this question) completed medical residence, 42 of whom (56.8\%) had graduate degrees, and 47 of whom (63.5\%) held the title of specialist. These results are presented in Table 1.

It can be seen in Figure 1 that 31 physicians (41.9\%) knew about

Table 1. Education levels of the orthopedic physicians interviewed, practicing in Salvador/BA.

\begin{tabular}{c|c|c}
\hline Titles & $\mathbf{n} / \mathbf{N}$ & $\%$ \\
\hline Resident & $64 / 74$ & 86.5 \\
\hline Graduate degree & $42 / 74$ & 56.8 \\
\hline Specialist & $47 / 73$ & 63.5 \\
\hline
\end{tabular}


at least one of the NP diagnostic scales and that, of these, only 20 $(64.5 \%)$ use this tool in their clinical practice, which represents $70.3 \%$ of the total sample studied, as shown in Table 2.

Of the 31 physicians who reported knowing about at least one of the scales, 8 (25.8\%) use LANSS in their clinical practice as a tool to diagnose neuropathic pain, 7 (22.6\%) use DN4, and 11 $(35.5 \%)$ do not use any tool, as shown in Figure 2. Figure 3 shows the relative frequencies of scale utilization within the group that referred to using them, disregarding those who know about them but do not use them.

In relation to time practicing, the median was 13.5 years. When we cross-referenced the variables of time practicing and knowledge of diagnostic tools, we found that the time practicing is greater among the physicians who do not know about the scales, although without a statistical difference $(p=0.096)$. The mean time practicing among those who know about the scales was 14 years $( \pm 12.4)$, while the mean time for those who did not know about them was 19.7 years $( \pm 14.8)$, as shown in Figure 4 .

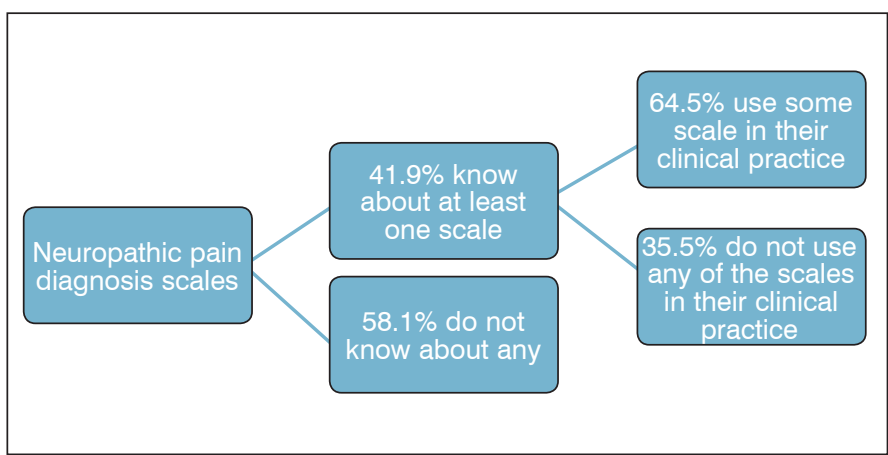

Figure 1. Percentages of frequency of knowledge of the NP diagnosis scales by the orthopedists interviewed, practicing in Salvador/BA in 2017, and frequency of use of the scales among those who know about them.

Table 2. Absolute frequencies and percentages of knowledge and use of NP diagnosis tools by the orthopedists interviewed, practicing in Salvador/ BA in 2017.

\begin{tabular}{c|c|c}
\hline \multirow{2}{*}{ Know about at least one of the scales } & & $\mathbf{n} / \mathbf{N}(\%)$ \\
\cline { 2 - 3 } & Yes & $31 / 74(41.9)$ \\
\hline \multirow{2}{*}{ Use at least one of the scales } & Yes & $43 / 74(58.1)$ \\
\cline { 2 - 3 } & No & $52 / 72(70.3 \%)$ \\
\hline
\end{tabular}

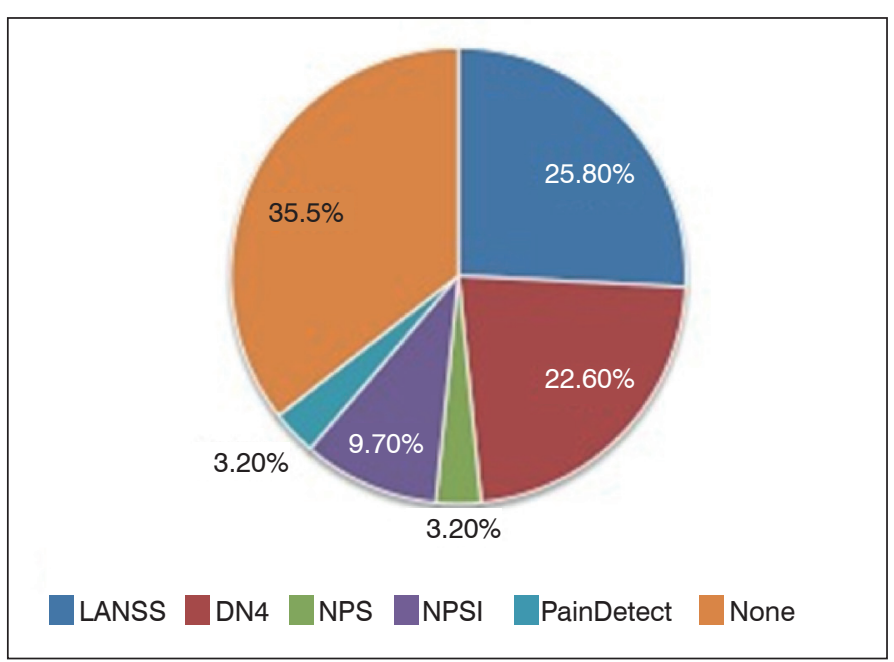

Figure 2. Percentage use of the NP diagnosis tools by the orthopedists interviewed.

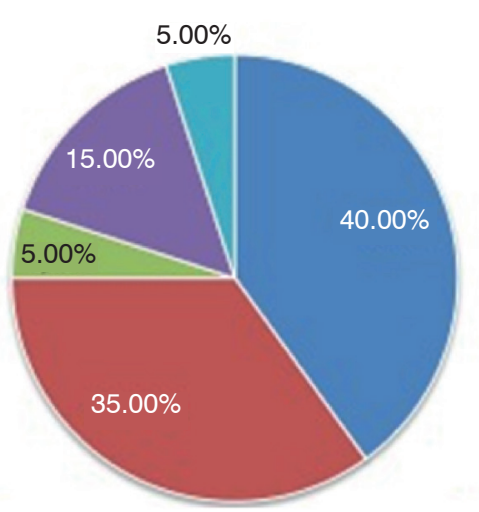

LANSS DN4 NPS NPSI PainDetect

Figure 3. Scales most used by the orthopedists in their clinical practice.

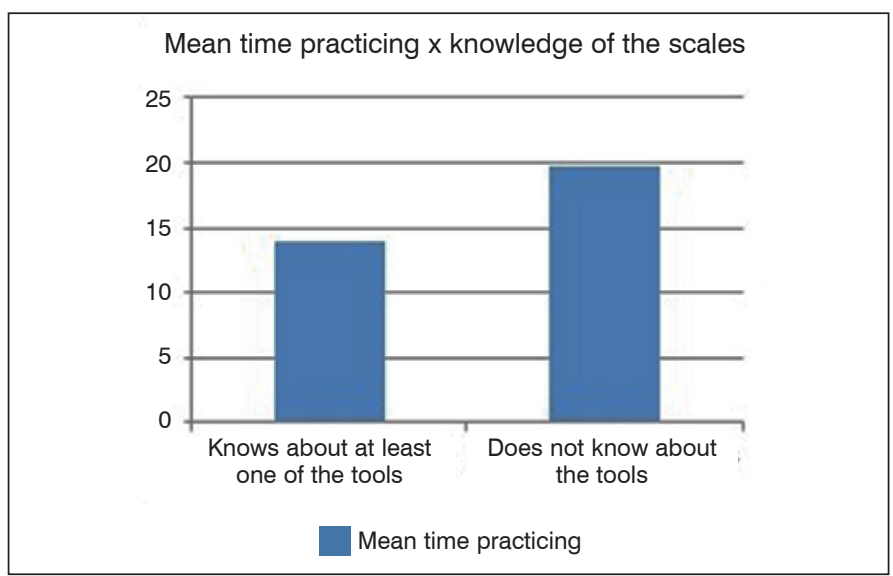

Figure 4. Relation between time practicing and knowledge of the NP diagnosis tools by the orthopedists interviewed, practicing in Salvador/BA in 2017.

\section{DISCUSSION}

One methodological obstacle was the scarcity of studies on the subject, both local and international, making comparative analysis difficult. Little has been published on orthopedists' knowledge about methods to diagnose neuropathic pain. In this study, we observed that $70 \%$ of the orthopedic physicians did not know about the NP diagnosis and assessment scales, and $35.5 \%$ of those who knew about them do not use them. Further research is needed to understand the reasons why orthopedic physicians do not use the NP diagnostic tools despite the low cost and ease of application.

Among the scales used by the orthopedists interviewed, the LANSS and the DN4 were the most often referenced. The LANSS (Leeds Assessment of Neuropathic Symptoms and Signs) was developed to serve as an indicator of a predominantly neuropathic versus nociceptive pain process, that is, to differentiate neuropathic from non-neuropathic pain. ${ }^{12}$ This tool is based on an analysis of the description of sensitivity and on an examination of sensory deficits, assessing the physical examination symptoms and signs, and the answers refer to the pain felt over the past week. Eckeli et al., in their review of diagnostic tools, found sensitivity and specificity of $85 \%$ and $80 \%$, respectively, for the LANSS. The DN4 (Douleur neuropathique 4 questions), an NP screening tool that is also useful in differentiating NP from nociceptive pain, showed a sensitivity of $83 \%$ and a specificity of $90 \%{ }^{13}$

In our study, it was revealed that, even though there was no statistically significant difference, orthopedists who graduated longer ago had less knowledge of NP diagnostic tools. From this arises 
the ever-valid discussion about the need for medical professionals to continuously update their knowledge. The health field, and medicine in particular, is constantly changing, given that new diseases are discovered and new treatments and diagnostic methods are continuously being elucidated by science. A recent Harvard study, published in the British Medical Journal, reported that the patients of older physicians have a higher rate of mortality than those of younger doctors. The authors argue that this is due to the fact that more experienced physicians generally follow the knowledge they acquired in their initial training, not seeking to update themselves. They analyzed 30-day mortality and readmissions for a random sample of over 700,000 elderly patients in hospitals between 2011 and 2014. Adjusted for variables that could skew the results, the 30 -day mortality rates were $10.8 \%$ for doctors less than 40 years of age, $11.1 \%$ for doctors between 40 and 49 years of age, $11.3 \%$ for doctors aged between 50 and 59 , and $12.1 \%$ for doctors 60 years of age or older. ${ }^{14}$ Even though the skills and knowledge accumulated by more experienced physicians may lead to improved quality of care, it is suggested their skills become outdated as scientific development, technology, and clinical guidelines evolve.

\section{CONCLUSION}

This study revealed that orthopedic physicians do not have extensive knowledge of the tools available to assess and diagnose neuropathic pain, being known by fewer than half of those interviewed. It was also shown that those with more time in practice knew less about these tools. Even among those who knew about the scales, more than a quarter did not use them. Among the scales used by the physicians interviewed, the LANSS and the DN4 are the most present in their clinical practices, one of them being used by $48.4 \%$ of the physicians who said they knew about neuropathic pain scales.

A more comprehensive study is needed to try to understand the reasons why NP diagnosis tools are not used by orthopedic physicians, despite their advantages and the importance in assisting early diagnosis and differentiation between the types of neuropathic pain.

All authors declare no potential conflict of interest related to this article.

CONTRIBUTION OF THE AUTHORS: Each author made significant individual contributions to this manuscript. MARML (0000-0002-3519-1025) ${ }^{\star}$, MAA (0000-0001-8597-7440)*, DDS (0000-0002-5087-1336)*: Contributed substantially to the design of work, acquisition, analysis and interpretation of data for the work; participated actively in the elaboration of results; carried out the writing of the work and critical revision of its intellectual content, besides the revision and approval of the final version of the manuscript. *ORCID (Open Researcher and Contributor ID)

\section{REFERENCES}

1. Fuchs M, Cassapian MR. A terapia ocupacional e a dor crônica em pacientes de ortopedia e reumatologia: revisão bibliográfica. Cad Ter Ocup. 2012;20(1):107-119.

2. Miranda CCV, Seda Junior LF, Pelloso LRCA. New physiological classification of pains: current concept of neuropathic pain. Rev Dor. 2016;17(Suppl 1):S2-4.

3. Backonja MM, Krause SJ. Neuropathic pain questionnaire: short form. Clin J Pain. 2003;19(5):315-6

4. Cardoso MG, Weinstock JG, Sardá JJ. Adhesion to neuropathic pain treatment. Rev Dor. 2017:17(Suppl 1):S107-9

5. Dworkin RH, Backonja M, Rowbotham MC, Allen RR, Argoff CR, Bennett GJ, et al. Advances in neuropathic pain: diagnosis, mechanisms, and treatment recommendations. Arch Neurol. 2003:60(11):1524-34

6. Barros GAM, Colhado OCG, Giublin ML. Clinical presentation and diagnosis of neuropathic pain. Rev Dor. 2016:17(Suppl 1):S15-9.

7. Schestatsky P, Nascimento OJM. What do general neurologists need to know about neuropathic pain? Arq Neuropsiquiatr. 2009;67(3-A):741-9
8. Haanpää M. Clinical Examination of a Patient with Possible Neuropathic Pain. In: Raja S vSC, editor. Pain 2014 Refresher Courses - 15th World Congress on Pain. Washington: IASP Press; 2014. p. 201-6p.

9. Alves Neto O, Costa CMC, Siqueira JTT, Teixeira MJ (org.). Dor: princípios e práticas. Porto Alegre: Artmed; 2009. p.495-7.

10. Stump PR, Kobayashi R, Campos AW. Low back pain. Rev Dor. 2016:17(suppl 1):s63-6.

11. Kopf A, Patel NB. Guia para o tratamento da dor em contextos de pouco recursos. Seattle: IASP Press; 2010. p. 22-4

12. Schestatsky P. Definição, diagnóstico e tratamento da dor neuropática. Rev HCPA. 2018;28(3):177-87.

13. Eckeli FD, Teixeira RA, Gouveia AL. Neuropathic pain evaluation tools. Rev Dor 2016;17(Suppl 1):S20-2

14. Tsugawa Y, Newhouse JP, Zaslavsky AM, Blumenthal DM, Jena AB. Physician age and outcomes in elderly patients in hospital in the US: observational study. BMJ. 2017;357: j1797. 